\title{
PROJECT PORTFOLIO MANAGEMENT AND QUALITY
}

doi: 10.2478/cqpi-2019-0004

Date of submission of the article to the Editor: 05/05/2019

Date of acceptance of the article by the Editor: 29/05/2019

Szczepaniak Waldemar - orcid id: 0000-0003-2608-1534

Czestochowa University of Technology, Poland

Abstract: Main objective of the study is to analyse the impact of portfolio management on the level of quality in EU projects implemented in public universities. First part of the article is theoretical and prepared on the basis of a critical analysis of literature in the field of quality management in projects and project portfolios. Second part of the text was based on primary data collected during preliminary survey conducted among EU project managers implemented in public technical colleges in the 2014-2020 financial perspective. Literature studies and results of own research allowed to identify and assess threats affecting the quality level in EU projects that result from transition from the level of individual project management to the level of project portfolio management. Continuous improvement of quality is a characteristic feature of organizations using quality management systems, so the article indicates the need to have an internal quality assurance system at universities. Importance of organizational units managing EU projects in universities in ensuring that products and results of a project are of high quality have also been underlined.

Keywords: quality assurance, quality management, improvement, project portfolios, project portfolio management.

\section{INTRODUCTION}

In modern organizations, an increasing number of activities are carried out in the form of projects. What is more, implementation of development strategy can take place by translating strategic objectives into project objectives, including EU projects. As a result management of projects and portfolios can become an element conditioning the efficient implementation of the strategy also in universities.

A project is a set of planned activities, involving various types of resources, which will be used to achieve adopted goal within a certain time interval. A specific type of projects are EU projects, i.e. undertakings strictly restricted by various guidelines, on both national and EU level. These projects are implemented within the framework of EU policies and are intended primarily to support socio-economic development of EU Member States (Domiter and Marciszewska, 2013). Both classic projects and EU ones require an appropriate level of management. Project management is a set of activities consisting of planning, organizing, managing and controlling projects aimed at achieving project objectives, involving project-related resources, both material and 
human (Lada and Kozarkiewicz, 2005). In project management, it is important to ensure an adequate level of quality management, costs, implementation time, resources, personnel, communication and risk.

In most organizations, many projects are carried out simultaneously, which allows them to be grouped into project portfolios. A portfolio of projects is a set of projects that are implemented in the unit at the same time, between which there are links resulting from a single source of funding, generating synergy or mutual balance. Project portfolio management is aimed at adapting the portfolio of projects to strategic goals of the organization (Kaiser, El Arbi, Ahlemann, 2015). Therefore, the strategic management theory (Killen, Jugdev, Drouin and Petit, 2012) applies to management of project portfolios. It should be noted that formalized strategic plans turn out to be insufficient in the face of turbulent changes in the environment (Kopmann, Kock, Killen and Gemündend, 2017). Therefore, it is necessary to strive for a better understanding of possibilities of applying a portfolio approach to project management and implementing strategies in this way as a response to growing uncertainty and complexity of business environments (Petit, 2012, Martinsuo, 2013).

Project portfolio management process includes selection of projects for the portfolio, defining their financing methods, implementation and monitoring of the progress of works ensuring achievement of objectives set by an entity (Kozarkiewicz, 2012). Managing the project portfolio should take into account the need to synchronize performance of tasks in individual projects and to counteract conflicts at the level of using limited resources of the organization, especially in the area of human resources (Sońta-Drączkowska and Ziemski, 2010). As in any process, and in project portfolio management, you can determine its performance measured by such measures as costs, time and quality (Lehnert, Linhart and Röglinger, 2016).

Implementation of EU projects by public universities is characterized by low flexibility resulting from strong restrictions due to legal regulations. On the one hand, concerning the functioning of public higher education institutions, including in particular public finance discipline. On the other hand, implementation of projects cofinanced from EU funds requires application of a number of guidelines, including in particular guidelines on eligibility of costs. Therefore, possibilities of full cost management and implementation time of EU projects are limited.

An area that plays a very important role in achieving the project's success, and which in the case of EU projects may be a particular distinguishing factor is the quality of the work carried out and results achieved in a given undertaking. Therefore, efficient quality management should play such an important role in the implementation of every EU project at universities.

As part of quality management, actions are taken to achieve the appropriate level of quality within the framework of implemented project (Zieliński, 2013; Gierulski, 2014). Quality, which is a collection of key features of the project determines the ability to meet defined requirements. This applies both to the quality of implementation processes and to the products and results of the project. Quality control plays a particularly important role in quality management, the aim of which is to ensure that effects of a project (products, results) will be in line with accepted quality requirements (Knop, Ingaldi and Smilek-Starczynowska, 2018; Borkowski, Knop and Szklarzyk, 2015; Knop 2017). Quality in the project is shaped mainly by internal quality assurance system functioning within the unit implementing the project. If, however, organization does not have such a system, then perhaps the quality management in 
the project can be based on generally available methodologies (Trocki and Juchniewicz, 2013), e.g. PRINCE2 (Wirkus, 2014). It should be emphasized that quality management and provision of a high level of quality of products and services may improve the business performance of the organization (Kim and Jung, 2015; Knop and Rosak-Szyrocka, 2016; Knop, 2017).

Project management offices play an important role in project and project portfolios management, the importance of which is also significantly increased in the field of project quality management (Ko and Kim, 2019). It can be pointed out that there are positive relationships between coordination and control in the project carried out by the project management offices and the quality of project portfolio management (Unger, Gemünden and Aubry, 2012). As a result, the increase in quality of project management has a positive impact on success of the entire portfolio (Jonas, Kock and Gemuenden, 2012), which in this case is usually measured as effectiveness of the project in terms of costs, time and quality (Lindhard and Larsen, 2016). The tools and techniques of quality and operational excellence will play a particularly important role in the case of large infrastructure projects, under which they can ensure sustainable success of the undertaking (Basu, 2017).

In managing multiple projects, replicating good solutions simultaneously contributes to the success of both individual projects and the entire portfolio. Analysis of the literature indicates primarily advantages of using portfolio approach in project management, including improvement of product quality and project results. However, multiplication of errors in projects may contribute to the failure of the entire portfolio. Thus, one can point to the existence of a cognitive gap in identification and analysis of portfolio management defects in the context of threats to achieve assumed level of quality. Therefore, the main objective of the study was to analyze impact of portfolio management on the level of quality in EU projects implemented in public universities. In pursuit of such a goal in the research process, identified threats influencing the level of quality in EU projects implemented in public universities, resulting from transition from individual project management to the level of project portfolio management were subject to analysis and evaluation.

\section{METHODOLOGY OF RESEARCH}

In order to identify factors determining transition from the level of individual project management to the level of project portfolio management in public universities, unstructured interviews with five managers of project management offices operating in public higher education institutions have been conducted. These interviews were aimed at gathering empirical material based on the use of open questions that allow the interlocutor to speak out in an open and free manner. Interviews were conducted from January to June 2017, i.e. at the time when public universities were at the stage of implementing many projects of the current financial perspective for 2014-2020. In the course of conducted non-structured interviews with managers of project management units in public universities, the advantages and disadvantages of managing project portfolios in public universities were identified (Szczepaniak, 2017). Results obtained were used to develop a questionnaire and conduct a preliminary survey among EU project managers carried out in public technical colleges in the 2014-2020 financial perspective. The aim of the study was the assessment of identified factors determining the transition from individual project management to the level of project portfolio management in public universities in Poland. The survey was 
prepared in an Internet form and placed on the webankieta.pl website. An invitation to complete the questionnaire was sent to $28 \mathrm{EU}$ project managers, 15 responses were obtained, which gave a feedback level at $53.6 \%$.

One of the questions posed to respondents was to assess identified drawbacks in the management of project portfolios at their universities. This question had a form of rank, in which the answers were based on a five-point Likert scale, where extreme answers were placed on the opposite sides, absolutely irrelevant - very important, so the central answer "indifferent" was treated as "neither high nor low", " average". Due to the ordinal scale used, statistical measures were used, such as: median, dominant, standard deviation.

\section{RESULTS}

As part of the preliminary study, the managers of EU projects implemented at universities under the current financial perspective assessed drawbacks in the management of project portfolios. The results of this assessment are presented in Table 1.

Table 1

Assessment of drawbacks in the management of project portfolios at public universities

\begin{tabular}{|c|c|c|c|c|c|c|c|c|c|c|}
\hline \multirow{3}{*}{ Specification } & \multicolumn{10}{|c|}{ Impact assessment } \\
\hline & \multicolumn{2}{|c|}{$\begin{array}{c}\text { Totally } \\
\text { irrelevant }\end{array}$} & \multicolumn{2}{|c|}{ Negligible } & \multicolumn{2}{|c|}{ Indifferent } & \multicolumn{2}{|c|}{ Significant } & \multicolumn{2}{|c|}{$\begin{array}{c}\text { Very } \\
\text { significan }\end{array}$} \\
\hline & $\mathrm{L}^{*}$ & $\mathbf{U}^{\star *}$ & $L^{*}$ & $\mathbf{U}^{* *}$ & $L^{*}$ & $\mathbf{U}^{\star *}$ & $L^{*}$ & $\mathbf{U}^{\star *}$ & $\mathbf{L}^{*}$ & $\mathbf{U}^{\star \star}$ \\
\hline $\begin{array}{l}\text { Overlapping of } \\
\text { deadlines related to } \\
\text { reporting obligations } \\
\text { that may result in } \\
\text { lower quality of work }\end{array}$ & 0 & 0 & 0 & 0 & 0 & 0 & 12 & 80,0 & 3 & 20,0 \\
\hline $\begin{array}{l}\text { If mistakes are made, } \\
\text { they will be } \\
\text { reproduced in many } \\
\text { projects }\end{array}$ & 0 & 0 & 0 & 0 & 0 & 0 & 6 & 40,0 & 9 & 60,0 \\
\hline $\begin{array}{l}\text { Favoring some } \\
\text { projects in the } \\
\text { portfolio at the } \\
\text { expense of others }\end{array}$ & 2 & 13,3 & 2 & 13,3 & 1 & 6,7 & 10 & 66,7 & 0 & 0 \\
\hline
\end{tabular}

Source: self elaboration based on research, $n=15$.

The first of the identified drawbacks in the management of project portfolios at universities, which was assessed, was the overlapping of deadlines related to reporting obligations that could result in lower quality of work. In the case of EU projects there will often be a situation of overlapping reporting periods, mainly quarterly and annual reports. Joint management of many EU projects is associated with the risk of a periodic significant increase in the burden of employees managing them. In the opinion of the majority of respondents this drawback was assessed as significant $(80.0 \%$ of responses). In addition, in the opinion of three respondents $(20.0 \%$ of responses) this drawback was assessed as very important. The result of 
lower quality of work may be a delay in the settlement of funds and the need to involve own funds for pre-financing activities in EU projects.

The second drawback assessed during the preliminary survey was duplication of errors in many projects. Respondents considered this drawback to be the most important of all assessed. It was indicated by $60.0 \%$ of respondents, and $40.0 \%$ as significant. None of the respondents indicated other answers. Bearing in mind the common guidelines on eligibility of costs in the current perspective and very similar guidance on information and promotion, improper interpretation and application of guidelines may result in non-eligible costs in many portfolio projects. Also, as part of executive processes, duplication of errors can significantly affect the quality of projects in the portfolio.

The last of indicated drawbacks concerned favoring some projects in the portfolio at the expense of others. The lower rating in this case is not a surprise and is adequate to the scale of threat. Most respondents indicated this drawback as significant $(66.7 \%$ of responses). $13.3 \%$ of respondents rated it as negligible and the same percentage of respondents considered this drawback as totally irrelevant. However, one of the respondents assessed it as indifferent to the management of EU projects portfolios at public universities.

In order to summarize results, appropriate ranks have been assigned to particular answers received, i.e. "very significant" responses 5 points, "significant" answers 4 points, "indifferent" answers 3 points, "negligible" answers 2 points, and "totally irrelevant" answers 1 point. obtained results of the assessment of advantages of managing project portfolios in public universities together with basic descriptive statistics are presented in table 2.

Table 2

Descriptive statistics of the assessment of drawbacks in the management of project portfolios at public universities

\begin{tabular}{|l|c|c|c|c|}
\hline \multicolumn{1}{|c|}{ Scope } & Average & Median & Dominant & $\begin{array}{c}\text { Standard } \\
\text { deviation }\end{array}$ \\
\hline $\begin{array}{l}\text { Overlapping of deadlines } \\
\text { related to reporting } \\
\text { obligations that may result } \\
\text { in lower quality of work }\end{array}$ & 4,2000 & 4 & 4 & 0,4140 \\
\hline $\begin{array}{l}\text { If mistakes are made, they } \\
\text { will be repeated in many } \\
\text { projects }\end{array}$ & 4,6000 & 5 & 5 & 0,5071 \\
\hline $\begin{array}{l}\text { Favoring some projects in } \\
\text { the portfolio at the expense } \\
\text { of others }\end{array}$ & 3,2667 & 4 & 4 & 1,1629 \\
\hline
\end{tabular}

Source: self elaboration

According to respondents, the biggest disadvantage of managing project portfolios at universities is the possibility of duplicating errors in many projects (average 4.6, median $=5$, dominant $=5$, with a standard deviation of 0.503 ). As a disadvantage of portfolio management, the overlapping of deadlines related to reporting obligations that could result in a decrease in the quality of work was rated high (mean 4.2, median $=4$, dominant $=4$, with a standard deviation of 0.4140 ). Only when favoring 
some projects in the portfolio at the expense of others, the impact force was rated lower $($ mean $=3,2667$, median $=4$, dominant $=4$, standard deviation $=1,1629$ ).

\section{DISCUSSION}

Universities are actively involved in the absorption of EU funds by implementing many projects at the same time. Therefore, it is possible to distinguish groups of projects for given activities, which from the point of view of strategic management can be treated as project portfolios due to similar goals and manage them as project portfolios. Portfolio management undoubtedly has many advantages. This is especially visible in the effective use of organization's resources, including human resources. However, one cannot overlook the risks associated with this form of project management, which may result in lower quality levels in projects.

During the research, particular attention was paid to two drawbacks that threaten achievement of assumed level of quality in projects managed from the level of the portfolio. The first one concerns management processes and is associated with periodic increase in work expenses during reporting periods, which may ultimately affect the quality of work. The second of identified defects has a much wider scope because it can concern not only management but also executive processes. As a result of duplicating wrong decisions in many projects, it may not only reduce the quality of work carried out, but also the quality of products and project results.

As part of portfolio management, the role of central cells managing projects, which are commonly referred to as project management offices and project portfolios, is particularly important. Portfolio management implemented by the project management office at the university should ensure the same level of management in all implemented projects. It will also enable monitoring consistency of objectives pursued and achieved production and result indicators within individual projects, as well as within the project portfolio with the university's development strategy. Moreover, improving the processes of sharing knowledge and experience, should positively affect the effective use of human resources.

\section{CONCLUSIONS}

In the modern world, achievement of a high level of quality is an inseparable element of implementation of each initiative. When applying quality management systems one should strive for continuous improvement of the quality level in organization, it also refers to the quality of products and results of projects co-financed from EU funds.

It should be pointed out that the management drawbacks of project portfolios identified in the research process represent a significant threat to the achievement of assumed level of quality in implemented projects. Therefore, it is necessary to search for solutions that eliminate negative impact of managing multiple projects at the same time on the level of quality in projects. These actions should be taken at the stage of quality planning, quality assurance as well as management and quality control. The key role here will be the role of organizational units responsible for project management at universities, including EU projects. The role of members of the project team will be to take necessary actions to ensure that products and results achieved are of high quality and meet assumed quality requirements.

Presented preliminary research results indicate importance of conducting further research in the field of analysis of impact of application of portfolio management theory on the quality of effects of EU projects in higher education. Results of these 
studies should contribute not only to improved quality of management process in EU projects but also should lead to increased absorption capacity of EU funds by universities.

\section{REFERENCES}

Basu, R., 2017. Quality management tools and techniques in major infra-structure projects, 6th International Conference on Reliability, Infocom Technologies and Optimization (Trends and Future Directions) (ICRITO), Noida, 114-126, DOI: 10.1109/ICRITO.2017.8342410.

Borkowski, S., Knop, K., Szklarzyk, P., 2015. Meaning of quality inspection and control methods during manufacturing process of metal sheet stampings, Manufacturing Technology, 15(3), 266-274.

Domiter, M., Marciszewska A., 2013. Zarządzanie projektami unijnymi. Teoria i praktyka, Difin, Warszawa.

Gierulski, W., 2014. Jakość projektu, In: Zarządzanie projektem, M. Wirkus, H. Roszkowski, E. Dostatni, W. Gierulski, PWE, Warszawa, 143-154.

Jonas, D., Kock, A., Gemuenden, H., 2012. Predicting Project Portfolio Success by Measuring Management Quality---A Longitudinal Study, IEEE Transactions on Engineering Management, 60, 1-12 DOI: 10.1109/TEM.2012.2200041.

Kaiser, M.G., El Arbi, F., Ahlemann, F., 2015. Successful project portfolio management beyond project selection techniques: Understanding the role of structural alignment, International Journal of Project Management, 33(1). 126-139, DOI: 10.1016/j.jproman.2014.03.002.

Killen, C.P., Jugdev, K., Drouin, N., Petit, Y., 2012. Advancing project and portfolio management research: Applying strategic management theories, International Journal of Project Management, 30(5), 525-538, DOI: 10.1016/j.ijproman.2011.12.004.

Kim, J.H., Jung, S.H., 2015. Study on CEO characteristics for management of public art performance centers, Journal of Open Innovation: Technology, Market, and Complexity, 1, 1-21, DOI: 10.1186/s40852-015-0007-7.

Knop K., 2017. Analysis of Risk of Nonconformities and Applied Quality Inspection Methods in the Process of Aluminium Profiles Coating Based on FMEA Results, Production Engineering Archives, 16, 16-21.

Knop, K., 2017. The Impact of Performance Improvement Achieved by the Closing Machine up to the Level of World-Class OEE on the Results of the Production Process, Terotechnology 2017, Materials Research Proceedings, 5, 117-122.

Knop, K., Ingaldi, M., Smilek-Starczynowska, M., 2018. Reduction of Errors of the Conformity Assessment During the Visual Inspection of Electrical Devices. In: Hamrol A., Ciszak O., Legutko S., Jurczyk M. (eds.), Advances in Manufacturing. Lecture Notes in Mechanical Engineering. Springer, Cham.

Knop, K., Rosak-Szyrocka, J., 2016. Evaluating and improving the effectiveness of the rolling mill in the production of medium steel sections in the selected company from the metallurgical industry, 25th Anniversary International Conference on Metallurgy and Materials (METAL 2016), Brno, Czech Republic, TANGER Ltd., Ostrava, 144-145.

Ko, J. H., Kim, D., 2019. The Effects of Maturity of Project Portfolio Management and Business Alignment on PMO Efficiency, Sustainability, 11(1), 238, 1-16, DOI: 10.3390/su11010238. 
Kopmann, J., Kock, A., Killen, C.P., Gemündend, H.G., 2017. The role of project portfolio management in fostering both deliberate and emergent strategy, International Journal of Project Management, 35(4), 557-570, DOI: 10.1016/j.jproman.2017.02.011.

Kozarkiewicz, A., 2012. Zarządzanie portfelami projektów. Wdrażanie i monitorowanie strategii organizacji za pomocą projektów, Wydawnictwo Profesjonalne PWN, Warszawa.

Łada, M., Kozarkiewicz, A., 2005. Podstawy controllingu projektów, Centrum Badań nad Projektami, Kraków.

Lehnert, M., Linhart, A., Röglinger, M., 2016. Value-based process project portfolio management: integrated planning of BPM capability development and process improvement, Business Research, 9(2), 377--419, DOI: 10.1007/s40685-016-00365.

Lindhard, S., Larsen, J.K., 2016. Identifying the key process factors affecting project performance, Engineering, Construction and Architectural Management, 23(5), 657-673, DOI: 10.1108/ECAM-08-2015-0123.

Martinsuo, M., 2013. Project portfolio management in practice and in context, International Journal of Project Management, 31(6), 794-803, DOI: 10.1016/j.ijproman.2012.10.013.

Petit, Y., 2012. Project portfolios in dynamic environments: Organizing for uncertainty, International Journal of Project Management, 30(5), 539-553, DOI: 10.1016/j.ijproman.2011.11.007.

Sońta-Drączkowska, E. Ziemski, W., 2010. Zarządzanie projektami w organizacjach procesowych. Opere et Studio pro Oeconomia, 7, 25-40.

Szczepaniak, W., 2017. Zarządzanie portfelami projektów unijnych w uczelniach publicznych, In: Zbiór prac naukowych. Współczesne problemy ekonomii - między teorią a praktyką gospodarczą w aspekcie różnorodności, M. Romanowska, M. Chudzicki (eds.), Polskie Towarzystwo Ekonomiczne Oddział w Częstochowie, Częstochowa, 116-124.

Trocki, M., Juchniewicz, M., 2013. Zarządzanie jakością w projekcie, In: Nowoczesne zarządzanie projektami, M. Trocki (ed.) PWE, Warszawa, 309-312.

Unger, B. N., Gemünden, H. G., Aubry, B., 2012. The three roles of a project portfolio management office: Their impact on portfolio management execution and success, International Journal of Project Management, 30, 608-620, DOI: 10.1016/j.jproman.2012.01.015

Wirkus, M., 2014. Metodyki zarządzania projektami - przegląd, In: Zarządzanie projektem, M. Wirkus, H. Roszkowski, E. Dostatni, W. Gierulski, PWE, Warszawa, 183-208.

Zieliński, G., 2013. Narzędzia przyczynowo-skutkowe w doskonaleniu jakości realizacji projektów, In: Zarządzanie projektami i procesami. Teoria i przypadki praktyczne, M. Wirkus (ed.), Difin, Warszawa, 185-204. 